\title{
A randomised single blind control study to assess the effect of intrapartum amnioinfusion on maternal caesarean section rate and fetal outcome in a tertiary care centre
}

\author{
Michelle Fonseca, Jyotsna S. Dwivedi*
}

Department of Obstetrics and Gynecology, LTMMC and GH, Sion, Mumbai, Maharashtra, India

Received: 08 September 2017

Accepted: 11 September 2017

\section{*Correspondence:}

Dr. Jyotsna S. Dwivedi,

E-mail: jyotsdwivedi@gmail.com

Copyright: (C) the author(s), publisher and licensee Medip Academy. This is an open-access article distributed under the terms of the Creative Commons Attribution Non-Commercial License, which permits unrestricted non-commercial use, distribution, and reproduction in any medium, provided the original work is properly cited.

\begin{abstract}
Background: The procedure of instilling normal saline/Ringer's lactate into the uterine cavity is called amnioinfusion. Objective of present study was to assess the effect of intrapartum amnioinfusion on maternal caesarean section rate and fetal outcome in a tertiary care centre in cases of meconium stained amniotic fluid.

Methods: A total of 160 women at term in labor with meconium stained amniotic fluid were randomized into two groups: study and control group. The study group received transcervical amnioinfusion at detection of MSAF. The control group was given the routine obstetric care. Both groups were started on $\mathrm{O} 2$ and intrapartum monitoring. The outcomes in both groups were analyzed statistically.

Results: The control group had caesarean section rate of $45 \%$ and in the study group it was $31.25 \%$. The difference was statistically significant. The outcome in the neonate was assessed on the parameters such as respiratory distress, neonatal intensive care unit admission, meconium aspiration syndrome, neonatal deaths.

Conclusions: Amnioinfusion in cases of meconium stained amniotic fluid cases significantly reduces the risk of meconium aspiration syndrome. It also decreases the need for operative intervention thus reducing the risk of maternal morbidity and mortality.
\end{abstract}

Keywords: Amnioinfusion, Meconium aspiration syndrome, Neonatal death

\section{INTRODUCTION}

The procedure of instilling normal saline/ Ringer's lactate into the uterine cavity is called amnioinfusion. The procedure can be done in antepartum and intrapartum period. The aim of this procedure is to replace the amniotic fluid. Amnioinfusion is considered as a method of preventing or relieving umbilical cord compression. ${ }^{1}$

Meconium aspiration syndrome complicates 1.7 to $35.8 \%$ of deliveries. ${ }^{2-5}$ It has been proved that amnioinfusion significantly decreases the rate of meconium aspiration syndrome in fetus and also the rate of caesarean section in mother. ${ }^{6}$

The objective of the present study was to assess the effect of intrapartum amnioinfusion on maternal caesarean section rate and fetal outcome in a tertiary care center.

Objective of present study were to assess the rate of operative delivery (LSCS) in patients with meconium stained amniotic fluid following amnioinfusion and to assess the fetal outcome in patients receiving the amnioinfusion. 


\section{METHODS}

The study was conducted in Department of Obstetrics and Gynecology at a tertiary health care centre, Mumbai. Total 160 pregnant patients were selected after fulfilling the inclusion and exclusion criteria. The study was carried for a period of one year from June 2016 to June 2017 after getting clearance from the institutional ethics committee.

\section{Inclusion criteria}

- $\quad$ Single live intrauterine gestation more than 37 weeks

- Cephalic presentation

- Active stage of labour

- Moderate to thick meconium stained amniotic fluid without fetal distress

\section{Exclusion criteria}

- Multiple gestation

- Cephalopelvic disproportion

- Uterine anomalies

- Previous operative delivery

- Active genital lesion.

- Malpresentations

- Maternal febrile illness

- Any known medical disorder such as heart disease, diabetes, pulmonary tuberculosis, asthma etc.

The patients were randomly divided into two groups i.e. study and control group using computerized randomization. Control group was the group which received continuous fetal monitoring, where as in the study group amnioinfusion was done. Amnioinfusion was carried out by inserting the ryle's tube transcervically in the uterus and $500 \mathrm{ml}$ of normal saline at 37 degree celsius was inserted into the uterine cavity over 30 minutes.

Oxygen was started at 5 litres per minute. Fetal heart sound monitoring was done every 15 minute in the first stage and progress of labour was documented on partograph. Caesarean section was done in both groups upon detection of fetal distress.

\section{Statistical analysis}

The data was statistically analysed using Fisher's exact test with Yate's correction using SPS software.

\section{RESULTS}

The two groups were studied with respect to the age, parity, average gestational age, average cervical dilatation at detection of meconium stained amniotic fluid, time interval between detection of meconium and delivery, mode of delivery as well as fetal outcome was compared with respect to APGAR score at 1 minute and 5 minutes post-delivery, presence of respiratory distress, meconium below the vocal cords, meconium aspiration syndrome and perinatal death in both the groups.

Table 1: Baseline parameters.

\begin{tabular}{|c|c|c|}
\hline & $\begin{array}{l}\text { Study group } \\
(\mathrm{n}=\mathbf{8 0})\end{array}$ & $\begin{array}{l}\text { Control group } \\
(\mathrm{n}=\mathbf{8 0})\end{array}$ \\
\hline Mean age & 26.5 & 28 \\
\hline Mean birth weight & $2576 \mathrm{gm}$ & $2468 \mathrm{gm}$ \\
\hline Mean gestational age & 37weeks 4 days & 37weeks 1 day \\
\hline \multicolumn{3}{|c|}{ Pregnancy complications } \\
\hline IUGR & 13 & 15 \\
\hline Postterm & 5 & 3 \\
\hline preeclampsia & 18 & 21 \\
\hline $\begin{array}{l}\text { Mean cervical } \\
\text { dilatation at the time } \\
\text { of detection of } \\
\text { meconium }\end{array}$ & $5.6 \mathrm{~cm}$ & $6.8 \mathrm{~cm}$ \\
\hline $\begin{array}{l}\text { Mean time interval } \\
\text { between detection of } \\
\text { meconium and } \\
\text { delivery }\end{array}$ & $3.2 \mathrm{hrs}$ & $2.8 \mathrm{hrs}$ \\
\hline
\end{tabular}

Table 2: Fetal parameters at birth.

\begin{tabular}{|llll|}
\hline & $\begin{array}{l}\text { Study } \\
\text { group }(\mathrm{n}=80)\end{array}$ & $\begin{array}{l}\text { Control } \\
\text { group }(\mathrm{n}=80)\end{array}$ & $\begin{array}{l}\mathrm{P} \\
\text { value }\end{array}$ \\
\hline $\begin{array}{l}\text { APGAR score } \\
\text { at 1 minute }<7\end{array}$ & 11 & 30 & 0.0005 \\
\hline $\begin{array}{l}\text { APGAR score } \\
\text { at 1 minute }>7\end{array}$ & 69 & 50 & 0.0005 \\
\hline $\begin{array}{l}\text { APGAR score } \\
\text { at 5 minutes }<7\end{array}$ & 4 & 16 & 0.0073 \\
\hline $\begin{array}{l}\text { APGAR score } \\
\text { at 5 minutes }>7\end{array}$ & 76 & 64 & 0.0073 \\
\hline $\begin{array}{l}\text { Presence of } \\
\text { respiratory } \\
\text { distress at birth }\end{array}$ & 7 & 19 & 0.0172 \\
\hline
\end{tabular}

Table 3: Maternal and fetal outcome.

\begin{tabular}{|llll|}
\hline & $\begin{array}{l}\text { Study } \\
\text { group } \\
(\mathrm{n}=80)\end{array}$ & $\begin{array}{l}\text { Control } \\
\text { group } \\
(\mathrm{n}=80)\end{array}$ & P value \\
\hline $\begin{array}{l}\text { Caesarean section } \\
\text { percentage }\end{array}$ & $31.25 \%$ & $45 \%$ & 0.0075 \\
\hline $\begin{array}{l}\text { Outlet forceps } \\
\text { application }\end{array}$ & 3 & 2 & $\begin{array}{l}\text { Not } \\
\text { significant }\end{array}$ \\
\hline $\begin{array}{l}\text { Admission of } \\
\text { neonate to NICU } \\
\text { immediate } \\
\text { postdelivery }\end{array}$ & 4 & 10 & 0.16 \\
\hline $\begin{array}{l}\text { Meconium } \\
\text { aspiration } \\
\text { syndrome }\end{array}$ & 3 & 7 & 0.32 \\
\hline Neonatal death & 1 & 3 & 0.62 \\
\hline
\end{tabular}

\section{DISCUSSION}

Amnioinfusion is considered as one of the methods to reduce the fetal distress by replacing the amniotic fluid 
and reducing the presuure on the umbilical cord. As per the above results it could be seen that cases where the transcervical amnioinfusion was done the caesarean section rate was $30 \%$ and in the control group the caesarean section rate was $45 \%$. The main objective of this study was to evaluate the effect of amnioinfusion on the maternal and perinatal morbidity and mortality. Passage of meconium is considered as a sign of fetal distress and longer duration of stay of meconium in the amniotic fluid can lead to accumulation of meconium in and around the vocal cord. As in present study the average age of patient in study group was 26.5 years and that in control group was 28years. The average birth weight in the study group was $2576 \mathrm{gm}$ and that into the control group was $2468 \mathrm{gm}$. The LSCS percentage in study group was $31.25 \%$ and in the control group was $45 \%$ which is statistically significant. The NICU admissions in the study group were 4 and those in the control group were 10 which is statistically not significant. Similarly, the neonatal death in study group was 1 and in control group was 3, and statistically insignificant. However, the respiratory distress observed in control group was significantly more than that in study group.

Table 4: Comparison with other studies.

\begin{tabular}{|c|c|c|c|c|c|}
\hline & Present study & Sahis D et al ${ }^{7}$ & Partha $\mathrm{M}$ et al $^{8}$ & Rathore et $\mathbf{a l}^{9}$ & Bansal et $a^{10}$ \\
\hline Sample size of study group & 80 & 50 & 93 & 100 & 50 \\
\hline $\begin{array}{l}\text { Caesarean section percentage } \\
\text { in the study group }\end{array}$ & $31.25 \%$ & $10 \%$ & $19.3 \%$ & $21 \%$ & $20 \%$ \\
\hline Respiratory distress at birth & 7 & 8 & 3 & 1 & 2 \\
\hline Admission to NICU & 4 & 3 & Not studied & 3 & Not studied \\
\hline $\begin{array}{l}\text { Meconium aspiration } \\
\text { syndrome }\end{array}$ & 3 & 2 & 22.1 & 0 & 3 \\
\hline Neonatal death & 1 & Nil & 2 & 2 & 0 \\
\hline $\begin{array}{l}\text { Maternal morbidity (fever, } \\
\text { sepsis, secondary suturing) }\end{array}$ & 5 & 1 & 7 & Not studied & 4 \\
\hline
\end{tabular}

As it can be seen from the above table the various studies done on the similar topic had the caesarean section rates less than that in the control group where only monitoring was done and amnioinfusion was not considered. The caesarean section percentage in present study group was $31.25 \%$ which is more as compared to the other studies as due to continuous fetal monitoring using cardiotocograph, fetal distress was detected early. In the study group the respiratory distress was detected in 7 newborns at birth as compared to 19 cases in control group. Admission to NICU was needed in 3 cases out of the total 80 cases in whom amnioinfusion was considered. The total number of newborn admitted in NICU, in the control group were 10, however the data was not statistically significant. The neonatal death in the study group was 1 and that in the control group was 3 and statistically it wasn't significant. Amnioinfusion is associated with substantive improvements in perinatal outcome only in settings where facilities for perinatal surveillance are limited ${ }^{11}$. The mechanism of benefit is not clear as it is due to dilution of meconium or relief of oligohydramnios. Amnioinfusion is considered to reduce the vagal stimulation by reducing the oligohydramnios and the dilution also decreases the amount of meconium in the trachea.

\section{CONCLUSION}

We found that the caesarean section rate in the amnioinfusion group was significantly less as compared to the control group. The rate of meconium aspiration syndrome and respiratory distress was less in the study group as compared to the control group. There was no increase in maternal and neonatal infection rates and other complications due to amnioinfusion in this study. Therefore, intrapartum intrauterine amnioinfusion is useful procedure done using simple equipment in the absence of modern electronic fetal-monitoring facilities especially in low-resource settings.

Funding: No funding sources Conflict of interest: None declared

Ethical approval: The study was approved by the Institutional Ethics Committee

\section{REFERENCES}

1. Hofmeyr GJ, Xu H, Eke AC, Amnioinfusion for meconium stained liquor in labor. Cochrane Database Syst Rev. 2014;(2):CD 000014.

2. Das V, Shrivastava S, Preetikumar. Amnio infusion during labor complicated by meconium. J Obstet Gynecol India. 2001;51:105-7.

3. Sahu IM. Intrapartum amnio-infusion for meconium stained amniotic fluid. J Obstet Gynecol India. 2003;53:345-7.

4. Hourdequin P, Kauffmann E, Gabriel R, Jotterand $\mathrm{AD}$, Chatelet-Cheront C, Quéreux $\mathrm{C}$ et al. Amnioinfusion during labor: experience and review of the 
literature. Contracept Fertil Sex. 1999 Mar;27(3):222-30.

5. Macri CJ, Schrimmer DB, Leung A, Greenson JS, Paul RH. Prophylactic amnioinfusion improves outcome of pregnancy complicated by thick meconium and Oligohydramnios. Am J Obset Gynecol. 1992;167:117-121.

6. Fraser WD, Hofmeyer J, Lede R, Faron G, Alexander S, Goffinet F. Amnioinfusion for the prevention of the meconium aspiration syndrome. $\mathrm{N}$ Engl J Med. 2005 Sep 1;353(9):909-17.

7. Sahis D, Das S, Sarkar S, Char D, Saha TK. Intrapartum amnioinfusion in meconium-stained amniotic fluid: a case-control study. IOSR-JDMS. 2013;10 (6):04-7.

8. Mukhopadhyay P, Naskar T, Dalui R, Hazra S, Keya G, Bhattachrya D. Role of intrapartum amnioinfusion in meconium stained amniotic fluid. $\mathbf{J}$ Obstet Gynecol India. 2006;56(3):230-2.
9. Rathorea AM, Singh R, Ramji S. Randomized trial of amnioinfusion during labor with meconium stained amniotic fluid. BJOG. 2002;109:17-20.

10. Bansal N, Gupta V, Nanda A, Chaudhary P, Tandon A, Behl N. Intrapartum amnioinfusion in meconium stained liquor: a case- control study. J Obstet Gynecol India. 2013 Jun;63(3):164-7.

11. Choudhary D, Bano I, Ali SM. Does amnioinfusion reduce caesarean section rate in meconium- stained amniotic fluid. Arch Gynecol Obstet. 2010 Jul;282(1):17-22.

Cite this article as: Fonseca M, Dwivedi JS. A randomised single blind control study to assess the effect of intrapartum amnioinfusion on maternal caesarean section rate and fetal outcome in a tertiary care centre. Int J Reprod Contracept Obstet Gynecol 2017;6:4347-50. 